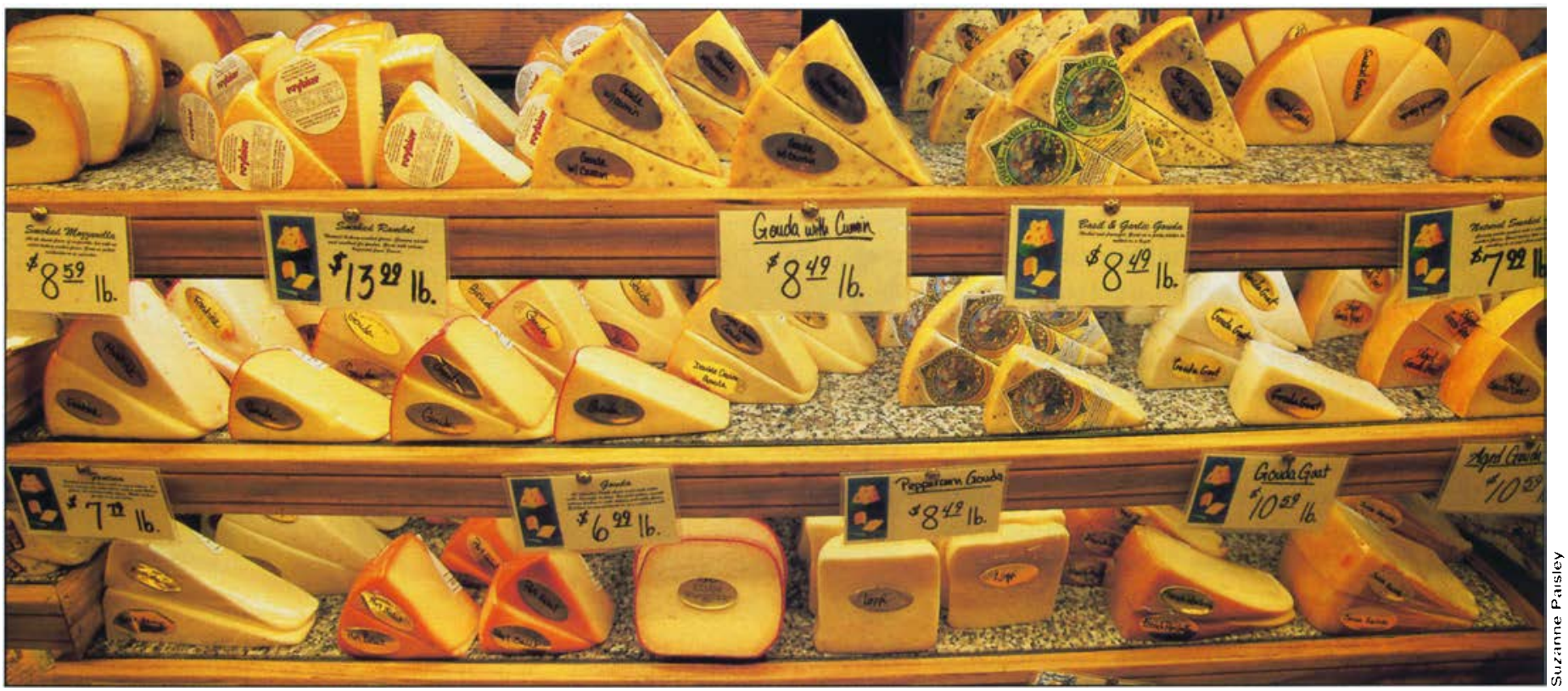

After the Gold Rush, Californla agriculture consisted primarily of cereals and livestock. Today, we grow a wide variety of high-value crops and create value-added products such as cheese.

\title{
Structural adjustment, resources, global economy to challenge California agriculture
}

\author{
Warren E. Johnston a Harold O. Carter
}

\begin{abstract}
California agriculture now faces perhaps its greatest challenges: to maintain productivity in the face of rapid population growth, compete effectively for global markets and manage increasingly scarce natural resources. Intensification is a dominant feature of California agriculture, evident in the increase in fruits, vegetables, nuts and value-added products. But risk is also substantially greater in the production and marketing of these crops than in lessintensive commodities. Agriculture must confront and deal with heightened public concerns about food safety, clean water, pesticide use, groundwater contamination, worker safety, open space and the lon't-term sustainability of scarce natural resources, ecosystems and species. Nonetheless, we believe that California's agricultural sector has adapted and responded to similar challenges in the past and will continue to do so in the future.
\end{abstract}

Q alifornia agriculture is a highly efficient food, fiber and floriculture system. In the 1983 book, A Guidebook to California Agriculture, we wrote a chapter discussing current challenges and those relevant to the future. Our comments focused on four major policy issues: (1) growing concentration, (2) the availability of adequate water, (3) land use and (4) environmental problems. "All of these have drawn increasing attention in the 1970s and in the years to come will continue to be debated as policy issues in a complex and interdependent society," we wrote (Johnston and Carter 1983).

Despite significant progress, elements of these same issues can still be listed as challenges for the first quarter of the 21st century, although they have been modified by rapid developments of the past two decades.

In an environment of rapid, seemingly continuous change, California agriculture will, by 2025, experience adjustments and structural changes as farmers, ranchers and other decisionmakers respond to significant forces of change. In spite of enormous agricul- tural advancements in the 20th century and the current strength, diversity and depth of our food and fiber sector, California agriculture faces its greatest challenges: to maintain productivity in the face of rapid population growth, mount competition for global markets, and manage increasingly scarce natural resources (Carter and Goldman 1998).

\section{California agriculture today}

Following the Gold Rush, California agriculture consisted largely of producing food for a relatively small population and exporting cereals and livestock products. The sector has since evolved to encompass a much wider variety of high-value crops and products for domestic and export markets.

The state's physical resources include a forgiving climate, once adequate but now increasingly challenged water supplies, and fertile soils. To this, farm and ranch operators add sophisticated technology and management systems. Other factors include a well-organized input sector, 
the availability of adequate credit, a world-renowned research and education system, an efficient marketing system and supportive governmental policies (Siebert 1997).

The tempo of change has quickened over the past quarter-century. California farm sales tripled between 1975 and 1997 , from $\$ 8.5$ billion to $\$ 26.8$ billion, and now comprise one-eighth of the total cash receipts of U.S. agriculture. Agriculture provides $7.9 \%$ of California's gross state product, and creates, directly or indirectly, more than 1 in 10 jobs in the state (Carter and Goldman 1998). More than 350 different crops and commodities are produced by almost 74,000 farms. More than half the nation's fruits, nuts and vegetables are produced in California on only $3 \%$ of U.S. farmland (USDA 1999) (table 1).

The diversity of California's agricultural sector arises from the existence of many different types of farms. A few large commercial farms produce the bulk of production; in 1997, farms with more than $\$ 500,000$ of sales ( $10.7 \%$ of all farms) produced $84.3 \%$ of the total value of agricultural products. But small farms are also evident in the sector; $60 \%$ of all California farms are less than 50 acres. These include part-time or hobby farms $(26 \%$ produce less than $\$ 2,500$ each in sales) and small specialty farms producing high-value horticultural and niche products. Farming is the principal occupation of only $53 \%$ of California farm operators, with $29 \%$ of farmers working 200 days or more off-farm (USDA 1999). It is obvious to the careful observer that diversity in type of farms, in the scale of their operations and other important characteristics makes generalizations about California's agriculture difficult (Johnston 1997).

\section{Growth and intensification}

Intensification is a dominant feature of California agriculture, evident in the increased production and valueadded activities of farms and agricultural businesses. Value is added in marketing channels, for example, when nuts are processed in industrial and consumer products; vegetables are

TABLE 1. Top 20 California agricultural commodities and 1997 value of production

\begin{tabular}{llccc}
\hline \hline $\begin{array}{l}\text { California } \\
\text { rank }\end{array}$ & Commodity & $\begin{array}{c}\text { 1997 value of } \\
\text { production }\end{array}$ & $\begin{array}{c}\text { U.S. rank } \\
\text { million } \$\end{array}$ & $\begin{array}{c}\text { California share of } \\
\text { U.S. production }\end{array}$ \\
\hline 1 & Milk and cream & 3,626 & 1 & $\%$ \\
2 & Grapes & 2,819 & 1 & 17 \\
3 & Nursery products & 1,758 & 1 & 91 \\
4 & Cattle and calves & 1,323 & 5 & 5 \\
5 & Lettuce & 1,251 & 1 & $72^{*}$ \\
6 & Almonds & 1,127 & 1 & 100 \\
7 & Hay & 1,037 & 2 & 6 \\
8 & Cotton lint & 984 & 2 & 14 \\
9 & Tomatoes & 870 & 1 & $94 \dagger$ \\
10 & Flowers and foliage & 729 & 1 & 22 \\
11 & Strawberries & 686 & 1 & 82 \\
12 & Oranges & 587 & 2 & 4 \\
13 & Chickens & 473 & 1 & 92 \\
14 & Broccoli & 449 & 1 & 100 \\
15 & Walnuts & 352 & 1 & 24 \\
16 & Rice & 347 & 2 & 9 \\
17 & Carrots & 345 & 1 & 89 \\
18 & Eggs, chicken & 345 & 2 & 88 \\
19 & Lemons & 266 & 1 & 1 \\
20 & Garlic & 262 & & \\
\hline
\end{tabular}

Source: CDFA 1999.

* Head lettuce only. California share of U.S. production for leaf lettuce is $81 \%$.

$†$ Processing tomatoes only. California share of U.S. production for fresh market tomatoes is $31 \%$.

distributed as salad mixes, dips or snack packs; milk is transformed into cheese and other dairy products; wine is marketed in consumer-friendly size and price combinations; or basic meats are transformed into "ready-to-eat" meals.

The trend toward intensification is demonstrated by changes during the past two decades in the distribution of acreage and value of crop production among field crops, fruits and nuts, and vegetables. From 1980

to 1997 , acreage in field crops such as grain, beans and cotton declined relative to rising acreages of the more intensive fruit, nut and vegetable crops. In 1980 , field crops used $72 \%$ of cropland, but returned only $43 \%$ of the value, whereas fruits, nuts and vegetables grown on $28 \%$ of the acreage contributed $57 \%$ of the value. In 1997 , these more intensive, higher-valued, higher-risk crops amounted to $78 \%$ of the value, while using only $45 \%$ of acreage (fig. 1).

Risk is substantially greater in the production and marketing of perishable fruits and vegetables than in annual field-crop commodities. Investments in permanent plantings are large and must be paid back during the period of economic production. Costs associated with vegetable crops are significant and market demands can fluctuate widely within a single cropping season.

The current production environment is intensely competitive for land and water resources. There are

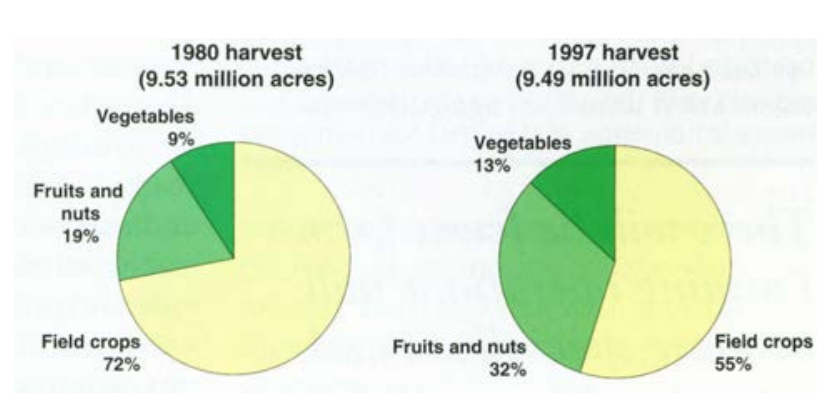




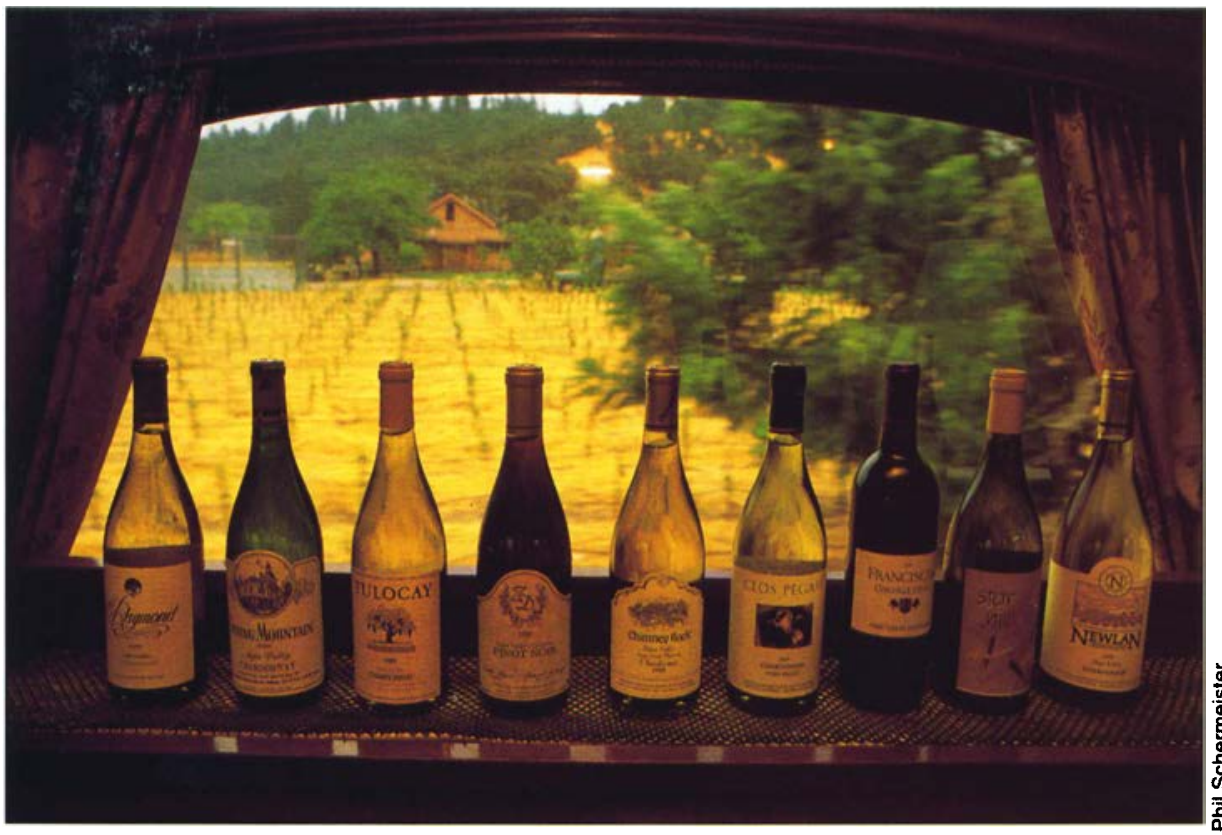

Intensification has become a dominant feature of California agriculture. In 1997, grapes were the state's second most valuable commodity, behind milk and cream. California wines are offered on the Napa Valley Wine Train.

ongoing needs for large amounts of capital for development, infrastructure, technology and production investments, along with sophisticated business and management skills. Capital flows into agriculture not only from individual entrepreneurs, but also from institutions and outside investors who demand economic returns commensurate with perceived commercial risks.

\section{The next quarter century}

California agriculture has generally operated with a more global market orientation than U.S. agriculture as a

There will be fewer farms. Farming operations will be more specialized and intensive. There will be continued pressure on agriculture from statewide population growth. And some agricultural operations will fail in the information-dependent and quickly changing environment of the new millennium. whole, in part due to its ability to export to the Pacific Rim. California accounted for slightly over $12 \%$ of U.S. agricultural exports in 1997 (Carter and Goldman 1998). The state also develops and adopts new technologies and has a longer history of addressing environmental and natural-resource management challenges in advance of most other agricultural regions. For example, UC scientists pioneered integrated pest management (IPM), and California was the first state in the nation to require pesticide-use reporting. The rest of the agricultural world has yet to adopt many of the practices already familiar to California producers and marketers.

Nonetheless, the Golden State's private and public decision-makers will need to deal with greatly expanded opportunities for international trade of agricultural products and additional environmental and resource constraints, while taking into account local conditions that affect growers.

The further intensification of California agriculture will be driven by forces such as global competition for domestic and export markets, agriculture's coexistence with a rapidly growing urban population, a tighter resource base, changing political and regulatory environments, and structural changes affecting the numbers and concentration of producers, suppliers, processors and marketers in the agricultural food and fiber system.

\section{Population and resources}

Today, California agriculture shares natural resources such as land, air and water with nearly 35 million people, compared with 10 million in 1950 . The state is projected to grow to about 50 million people by year 2025 (California Department of Finance 1998). A growing population inevitably generates pressures on land, water and air resources that greatly affect agriculture. Even if agriculture maintains its economic importance in California, its political power will wane as the state's growing urban population expresses new priorities and the pressures to reallocate natural resources increase.

Population pressure. With California's coastal areas heavily developed already, inland communities are under enormous pressure to accommodate housing, commercial and industrial development. The mid-and southern Central Valley, California's traditional agriculture production areas, are projected to be among the state's fastest growing regions in coming decades (Johnston 1991). Conflicts and tensions between growers and new residents at the rural-suburban interface will significantly affect many growers who are unable or prefer not to sell farmland for development. Many in agriculture are seeking improvements in land-use planning decisions along the rural-suburban fringe and in rural regions of the state, such as agricultural conservation easements and "Freedom to Farm" ordinances that inform new residents about what they may expect from living in an agricultural area (Medvitz et al. 1999).

Water supplies. The reality of finite water supplies within the state, concerns about declining water quality, and the consequences of evolving public policies that will likely reallocate quantities away from agriculture for in-stream and nonagricultural uses pose a significant concern to agriculture. Emerging water markets will reallocate water to nonagricultural users and quantities within agriculture from lower- to higher-valued crops (Sunding 2000). Many farmers will 
make production decisions with less than historically available quantities of irrigation water and higher levels of uncertainty in the 21st century.

Air quality. California has long experienced air-quality problems and agriculture has been perceived as a contributing factor. Regulations concerning dust, burning and pesticide drift are reducing agriculture-related pollution in the Central Valley, but air quality also continues to deteriorate due to urban growth with the addition of new industries, automobiles and other pollution sources. Diminished air quality affects plant health as well as human health. As ozone levels rise along transportation corridors, such as Highway 99 in the Central Valley, crop yields and profits are adversely impacted (Winer et al. 1991). Regulators have paid little or no attention to the effects of general economic activity on agricultural productivity.

\section{Regulatory challenges}

Agriculture must also confront and deal with heightened public concerns about food safety, clean water, pesticide use, groundwater contamination, worker safety, open space, and the long-term sustainability of limited natural resources, ecosystems and species.

Federal, state and local governments have enacted laws and regulations designed to address many of these concerns. California agriculture is generally recognized as the most stringently regulated of all 50 states. Regulatory standards within the state often exceed those of the federal government and/or competing farm states (Coppock 1996).

Myriad federal agencies regulate California agriculture, including the U.S. Environmental Protection Agency (U.S. EPA), Department of Agriculture, Fish and Wildlife Service and Bureau of Reclamation, as well as state agencies such as the California Environmental Protection Agency, Department of Public Health, Department of Food and Agriculture, State Air Quality Control Board and State Water Quality Control Board.

For example, in 1999 and 2000, U.S. EPA announced the cancellation of the pesticides chlorpyrifos and methyl parathion for many food-crop uses as well as a reduction of azinphos methyl for many fruits and vegetables. These restrictions are the first significant regulatory actions taken under the Food Quality Protection Act (FQPA), a 1996 law that requires U.S. EPA to re-evaluate more than 9,000 pesticide tolerances to reduce health risks to infants and children. U.S. EPA's evaluatory efforts are lagging behind announced schedules, leaving agriculture exposed to continued uncertainty.

The costs of regulation manifest themselves in many ways. Indirect costs to growers can affect business decisions, management flexibility, choice of products grown, resource allocation and investments. In a survey by the UC Agricultural Issues Center, about $85 \%$ of California farmers said they experienced increased paperwork and $70 \%$ changed their use of chemicals or medicinals as a result of government regulations (Coppock 1996). California farmers are particularly concerned about the burden of uncoordinated or duplicative regulations, arbitrary enforcement and the increasing numbers of regulations.

Clearly the policy choices of the next quarter-century will have significant impacts on California agriculture and how it competes on the global playing field. Continuing regulatory uncertainty and the lack of economically viable alternatives to current management practices affect competitiveness and economic performance. More growers will go out of business
The globalization of trade provides more choices for consumers, but also heightens the competition faced by growers. With major ports such as Oakland shipping to the Pacific Rim, California accounted for $12 \%$ of U.S. agricultural exports in 1997.

unless policy-makers place a higher priority on promoting the development of both efficient and environmentally friendly technologies and practices.

\section{Boom-and-bust cycles}

As the agricultural sector shifts toward greater dependence on highervalue perennial tree and vine crops and away from annual field and seed crops, incomes and profits may be subject to boom-and-bust cycles. Such cyclical behaviors have long been recognized in the livestock industry due to the long lead times and adjustment lags for breeding stocks relative to changing market demands for beef and pork products. With tree and vine 
crops, cycles occur because investment decisions are made far in advance of production due to time lags for land and water development, acquisition of nursery stock, and initial nonbearing periods ranging from 3 to 10 years.

In the past, California has seen several boom-and-bust cycles in the performance of perennial crops as new plantings come into production in excess of market demand. Commodity prices fall in response to increased production, and decapitalization results in lower-priced sales of already developed orchards.

Tree and vine crops have drawn capital into agriculture during the past decade because of attractive returns to growers and the availability of significant levels of outside investment and financing. For these crops, increases in bearing acreage from 1975 to 1997 range from $7 \%$ for walnuts to $3,500 \%$ for pistachios (table 2). Production has increased more than proportionately due to the adoption of higher-yielding varieties and improved cultural practices for newer plantings.

Tree and vine crops were expected to face near-term marketing uncertainties as significant new acreage comes into production in the early 2000s. For every 4.2 bearing acres of wine grapes in 1997, another acre was planted but not yet in production (table 2). In 2000, most of these wine-grape acres will have come into production, increasing total gross acreage about $80 \%$ over 1975 levels.

With the globalization of trade, non-U.S. agricultural producers can be expected to expand their exports. Asia

\section{California agricultural production, 1975 and 1997}

The production of field crops, fruits and nuts, and vegetables makes up the majority of the value of California's agricultural production. However, two additional sectors - livestock and nursery and nursery products - are also of great importance to the state's agricultural economy.

California's livestock sector includes capital-intensive dairy and poultry production, as well as the more traditional, extensive, rangelandbased production of cattle and sheep. Four of California's top 20 farm products in 1997 were livestock and poul-

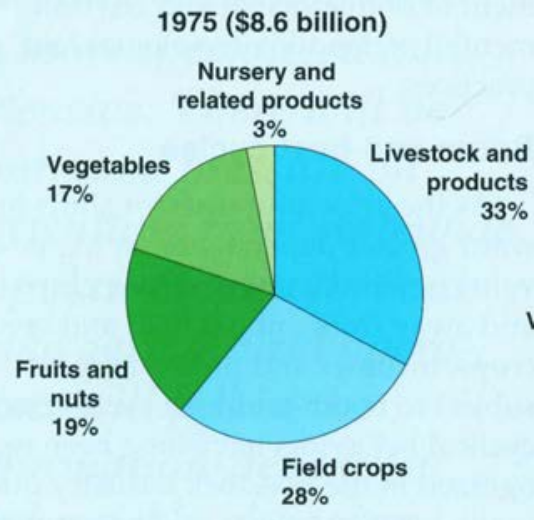

try: milk and cream (1), cattle and calves (4), chickens (13) and chicken eggs (18) (table 1, p. 17).

Nursery, flower and foliage production have grown enormously, associated with increased demands for perennial plantings in agriculture and to meet the flower and landscaping needs of California's growing population.

Over past 25 years, fruit and nut crops, vegetable crops, and nursery and nursery products have grown in importance while livestock and field crops have declined (fig. 1).

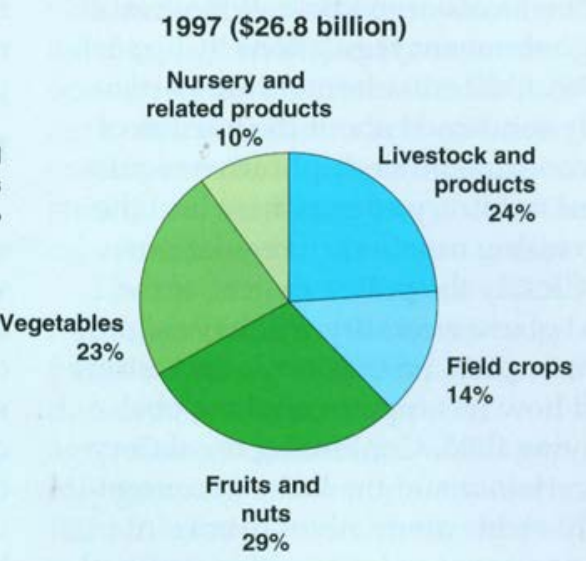

Fig. 1. Composition of California agricultural production, 1975 and 1997. Source: CDFA 1999.

and Southern Hemisphere nations such as Chile, Australia and South Africa are undergoing large increases in acreage of some perennial tree and vine crops. Consumers benefit from the availability of additional products, but U.S. and California producers will also face more competition in the future.

The outlook for producers and marketers will differ from crop to crop over the next quarter century, depending on global demands and supplies. Producers and financial institutions must diligently investigate long-term market conditions before expending significant capital on new production areas. For example, China is expected to be the largest walnut supplier in the world in coming years at the same time that California walnut acreage is increasing (Kirkpatrick 2000). If California growers are not extremely careful, they will experience recurrent periods of disequilibrium, and of longer duration than when annual crops dominated.

\section{Forces of change in system}

The transition from a commoditybased agricultural industry to one with differentiated, value-added products and a focus on the end-user is occurring nationwide. This shift has existed in California for at least the last quarter century and its ripple effects have spread throughout the food and fiber system.

Earlier, marketing outcomes were primarily determined by the response of consumers to available supplies of food and fiber. There has, however, been a progressive shift of power and control over time away from producers toward end users and those firms that have more intimate contact with consumers. Suppliers find that they must now respond to global consumer demands as well as those of intermediate processors and marketing agents; market power and control has shifted significantly to buyers who have intimate knowledge about consumer needs and desires that has generally been unavailable to growers. This is the new paradigm that now dominates much of the food and fiber system.

The structure of California's and the global agricultural business 
economy will be further transformed in the new millennium as a consequence of the continuing emergence of the new paradigm around the globe. We foresee four major " $\mathrm{C}$ " trends: concentration and consolidation, coordination, and contraction.

Concentration and consolidation. Size and information economies are significant when servicing final demands, assuring that product moves efficiently through the food and fiber system from producer to consumer. Increased concentration at the retail and institutional food-service levels reflects these two re-

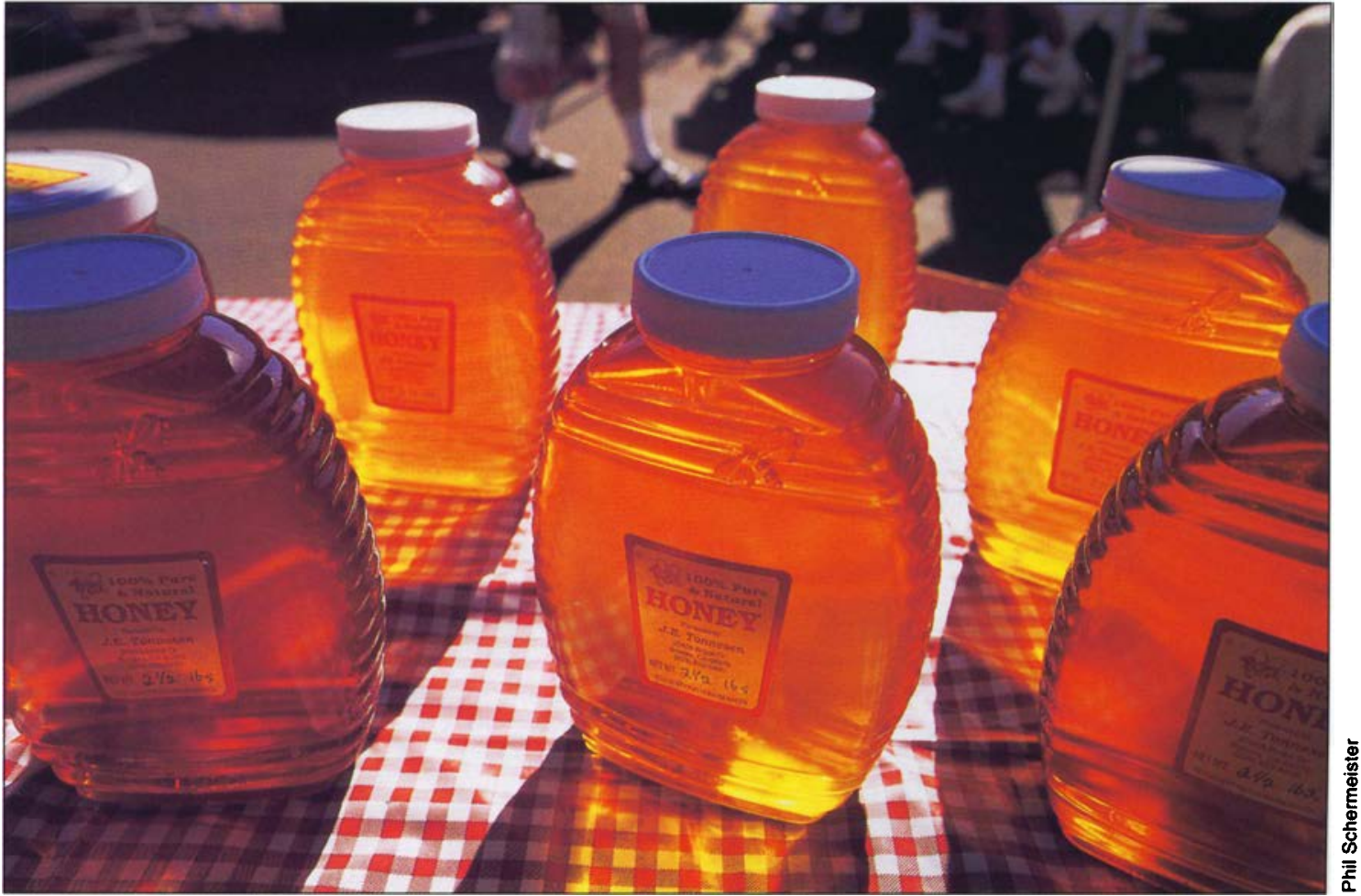

About $60 \%$ of California farms are small and produce high-value horticultural or niche products, such as honey at this farmers' market. In the 21st century the state's agriculture will be defined by consolidation, concentration, coordination and contraction.

dominant, reducing the number of competitors in many agricultural markets. Large supermarket chains use bar codes and other sophisticated means to collect information about consumer preferences, allowing them to profit further from their market dominance. The ownership of market information by larger, private firms is in sharp contrast to commodity agriculture's longstanding reliance on governmentgenerated information for farm-based decision making.

There has also been considerable consolidation among processing and marketing agents, the middle agents between producers and end-users in the food and fiber system, as they seek to maintain countervailing bargaining power in the marketplace. This consolidation is a direct response to the concentration that has occurred at the retail and food service levels.

With fewer, larger and more powerful entities between them and consumers, farmers, too, are forced to adopt strategies to become better integrated into the new business environment. The ability to supply larger volumes of produce meeting buyer specifications on a year-round basis will be favorably viewed by the larger firms that move product through the system beyond the farm gate. Producers will either grow as independent units by horizontal or vertical integration or respond to downstream market demands by alliances or other business arrangements.

Thus, concentration and consolidation is occurring throughout the food and fiber system for those firms that are primarily commercial. Smaller firms and farms will be viewed as less attractive business partners and may face the possibility of more frequent and acute fluctuations in receipts than larger, more commercial counterparts. To compete and operate efficiently as suppliers, farmers and ranchers will need to become much more sophisti- cated in their uses of and access to good-quality information. Small firms will be more successful in local and smaller niche markets, but at a disadvantage in competing effectively in the larger evolving markets for food and fiber.

Coordination. Many California growers are experienced in the use of negotiated market contracts with processors and marketers, selling directly without involving middlemen, except perhaps bargaining associations. Contractual arrangements specifying cultural, harvest and delivery conditions move buyers and sellers into closer relationships with each other. The practice assures that production will be sold and supplies purchased, reducing
TABLE 2. Tree and vine crop statistics, 1975 and 1997

\begin{tabular}{|c|c|c|c|c|c|}
\hline & $\begin{array}{c}\text { Bearing } \\
\text { acreage } \\
1975\end{array}$ & $\begin{array}{c}\text { Bearing } \\
\text { acreage } \\
1997\end{array}$ & $\begin{array}{c}\text { Increase } \\
1975 \text { to } 1997\end{array}$ & $\begin{array}{l}\text { Nonbearing } \\
\text { acreage } \\
1997\end{array}$ & $\begin{array}{l}\text { Ratio bearing to } \\
\text { nonbearing acreage } \\
1997\end{array}$ \\
\hline & & & $\%$ & & \\
\hline Almonds & 248,759 & 410,000 & +65 & 13,100 & 6.5 to 1 \\
\hline Pistachios & 1,666 & 60,000 & $+3,500$ & 13,400 & 4.6 to 1 \\
\hline Walnuts & 165,838 & 177,200 & +7 & 20,900 & 8.9 to 1 \\
\hline Table grapes & 63,124 & 76,700 & +20 & 13,100 & 5.8 to 1 \\
\hline Wine grapes & 225,161 & 329,000 & +46 & 78,300 & 4.2 to 1 \\
\hline
\end{tabular}

Source: CDFA 1999. 


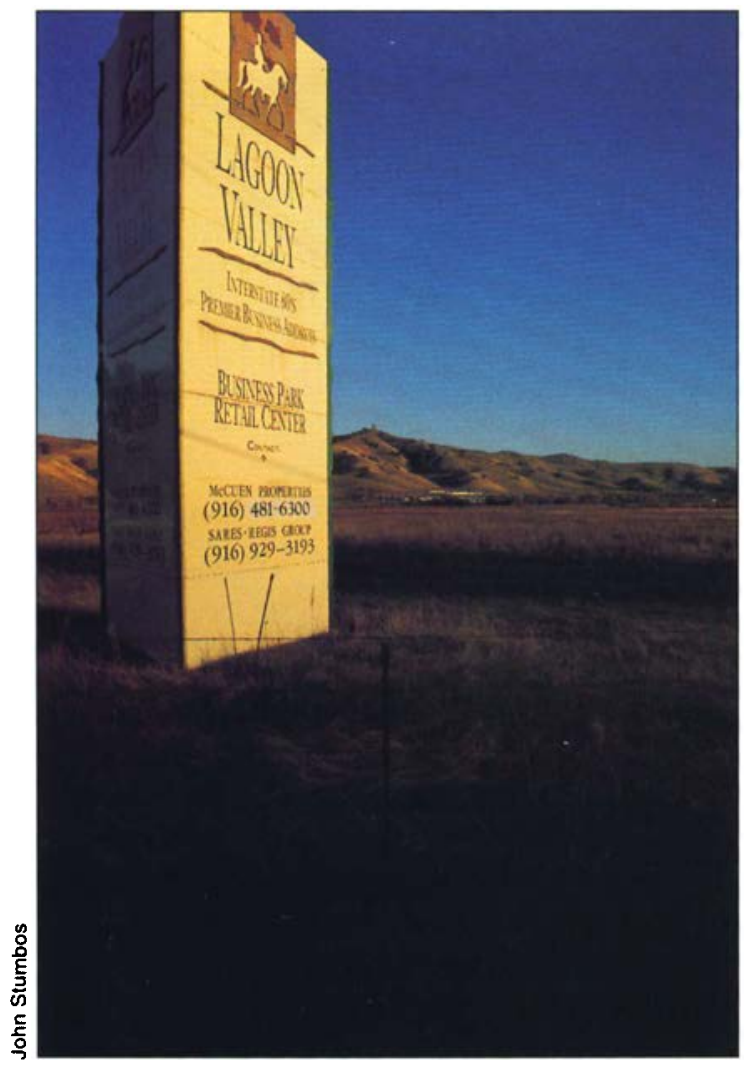

With new developments pushing into rural areas, farmers are seeking land-use changes such as conservation easements and "Freedom to Farm" statutes.

price risk and providing benefits to contracting parties. Terms of contracts are undergoing change as market and performance conditions change. The trends of greater coordination and contracting between suppliers and processors and marketers will surely intensify in the future. More attention needs to be focused on contractual alternatives as markets become more specialized to balance untoward market power and control that can result from continued concentration and consolidation in the food and fiber system.

Contraction. The information superhighway may further reduce the number of transactions and participants in the food and fiber system. If so, contraction will reduce the power of middlemen in the continuum between producers and consumers, and between producers and farm-input suppliers. The potential of business-tobusiness e-commerce will change the relative economic returns to participants. Economic benefits will flow to larger firms, consortiums of small firms, and growers who become profi- cient in the use of emerging information technologies, including business-to-business e-commerce options.

For example, growers are beginning to skip the middleman and connect with processors and marketers over the Internet; at the same time, they are doing more processing and direct-marketing themselves. Improved information about markets and competitors may lead to better decisions and could reduce adverse, cyclical commodity-price behavior.

\section{Future in focus: California agriculture in $\mathbf{2 0 2 5}$}

Many of the challenges faced by growers during the past quarter-century - natural resources, global competition, water supplies - will persist during the next 25 years, awaiting mitigation and solution in an environment of rapid change. All firms in the food and fiber system will be more closely related in real time and market signals will be transmitted to suppliers ever more rapidly.

We can make several obvious assertions with certainty about California agriculture in 2025. There will be fewer farms. Farming operations will be more specialized and intensive. There will be continued pressure on agriculture from statewide population growth. And some agricultural operations will fail in the informationdependent and quickly changing environment of the new millennium.

However, these sorts of changes are not new or unusual.

Such changes have long been a feature of California's agricultural sector, which continually adapts and responds to production and marketing challenges. The tempo of change will be amplified and accelerated by recent innovations and structural adjustments outside of farms. The chief coping strategies for growers during the next quarter-century will be those that recognize the altered structure of the food and fiber system and that master the realities and potential of new electronic information technologies. The most successful firms will be those that are strategically managed to ensure continued economic viability in a period of changing domestic and global markets, while minimizing uncertainties imposed by public attitudes, regulator decisions and more variable market outcomes.

W.E. Johnston and H.O. Carter are Professors Emeriti, Department of Agricultural and Resource Economics, UC Davis, and members of the Giannini Foundation of Agricultural Economics.

\section{References}

California Department of Finance, Demographic Research Unit. 1998. Race and Ethnic Population, Age and Sex Detail, 19702040. Sacramento, CA.

Carter HO, Goldman G. 1998. The Measure of California Agriculture: Its Impact on the State Economy. UC Agricultural Issues Center, Division of $\mathrm{Ag}$ and Nat Res. $62 \mathrm{p}$.

[CDFA] California Department of Food and Agriculture. 1999. 1998 California Agricultural Resource Directory. Sacramento, CA. $179 \mathrm{p}$.

Coppock R. 1996. Research Update:

Farmers say regulations complicate farming. Cal Ag 50(5):4-5.

Johnston WE. 1997. Cross sections of a diverse agriculture: Profiles of California's production regions and principal commodities. In: Siebert JB (ed.). California Agriculture: Issues and Challenges. UC Giannini Foundation of Agricultural Economics, Division of $\mathrm{Ag}$ and Nat Res. p 63-100.

Johnston WE. 1991. Land in the Central Valley: Competition for a finite resource flexibility vs. irreversibilities. In: Carter HO, Coppock R, Kennedy L (eds.). Resource Pressures: California's Central Valley. UC Agricultural Issues Center. p 43-56.

Johnston WE, Carter HO. 1983. Policy issues. In: Scheuring AF (ed.). A Guidebook to California Agriculture. Berkeley, CA: UC

Press. p 381-7.

Kirkpatrick S. 2000. Taking stock. Calif Farmer 283(9):27-31.

Medvitz AG, Sokolow AD, Lamp C (eds.). 1999. California Farmland and Urban Pressures. UC Agricultural Issues Center. 207 p. Siebert JB (ed.). 1997. California Agriculture: Issues and Challenges. UC Giannini Foundation of Agricultural Economics, Divison of Ag and Nat Res. 274 p.

Sunding D. 2000 . The price of water: Market-based strategies are needed to cope with scarcity. Cal Ag 54(2):56-63.

[USDA] U.S. Department of Agriculture. 1999. 1997 Census of Agriculture. Highlights of Agriculture: 1992 and 1997 Washington DC www.nass.usda.gov/census97/highlights/ ca/cast.txt.

Winer AM, Olszyk DM, Howitt R. 1991. Air: An endangered resource for California agriculture, 1990-2010. In: Carter HO, Coppock R, Kennedy L (eds.). Resource Pressures: California's Central Valley. UC Agricultural Issues Center. p 23-42. 